\title{
PUBLIC PURPOSE IN PUBLIC HOUSING: AN ANACHRONISM REBURIED *
}

\author{
By MYRES S. McDOUGAL $\dagger$ and ADDISON A. MUELLER*
}

"No immediate aim of the American people" is "more widely supported and more insistently voiced than the desire to attack the social evils of the slums and to provide decent living quarters for at least a portion of the underprivileged." So wrote the United States Senate Committee on Education and Labor in its unanimous recommendation of the United States Housing Act of 1937. ${ }^{1}$ Indeed it is now common knowledge that the all too recent slum clearance, low-rent public housing program of the United States Housing Authority, and of its some 600 cooperating local authorities, is but one of many related governmental responses-required by the failure of private institutions - to insistent public demands. ${ }^{2}$ In a country where "every third home" is substandard on "simple physical grounds alone" ("without considering overcrowding"), ${ }^{3}$ every needed and relevant power of government - planning, spending, taxing, condemning, owning, lending, policing, regulating - has been marshalled at every level - federal, regional, state, and local - for the achievement of a new public goal: the provision of healthful homes, in well planned communities, for all citizens, at prices that they can afford to pay. ${ }^{4}$ In

* A reply to Russell, Tax Status of Public Housing (1942) 28 A. B. A. J. 381, and a criticism of the decision of the Supreme Court of Ohio in Columbus Metropolitan Housing Authority v. Thatcher, 140 Ohio St. 38, 42 N. E. (2d) 437 (1942).

$\dagger$ Professor of Law, Yale Law School.

¥ Second-year student, Yale Law School.

The writers are indebted to Mr. Asher Lans, a former editor of the Yale LAw JourNAL, for helpful suggestions.

1. Sen. Rer. No. 933, 75th Cong., 1st Sess. (1937) 2.

2. The "public housing" with which this article is concerned is the housing furnished by local public authorities, aided by federal loans and subsidy, to low-income families for whom "private enterprise" has not been able to build an adequate supply of decent, safe, and sanitary dwellings and who have, therefore, been compelled to live in slum-type, substandard houses. For reasons none too obscure in the pressure-group organization of our society, it is this "public housing" which has been most subjected to legal attack. It should be noted, however, that all the recent governmental intervention in housing-even the government's assumption of formerly "private" risks through the FHA and the Federal Savings and Loan Insurance Corporation-are equally scrious departures from traditional laisse - faire economic concepts. An anthropological observer might find it hard to understand why all such intervention does not, in terms of traditional legal syntax, raise the same question of "public purpose" (see pages 43-45 infra).

3. Bauer, A Citizen's Gutde to Public Housing (1940) 16.

4. For elaboration of the familiar history of why this has come to pass, see: EuENstein, The Law of Public Housing (1940); Walker, Urban Bligit and Slums (1938); Abrams, Revolution in Land (1939); Bauer, Modern Housing (1934) and A Citizen's Guide to Public Housing (1940); Wood, Introduction to Housino 
addition to the United States Housing Authority and its cooperating state and local authorities, a host of other new agencies - the HOLC, the FHA, the Federal Home Loan Bank System, the Federal Savings and Loan Insurance Corporation, the Farm Security Administration, the TVA, and now the National Housing Agency and the Rent Division of OPA - all bear indubitable testimony to the fact that "housing" has in recent years in the United States achieved the status of a governmental function. ${ }^{5}$

For the past eighty years our courts have been accustomed to test such governmental assumption of a new function, if it requires the expenditure of public funds, by determining whether or not that function is for a "public purpose." But the phrase "public purpose" does

(1939); Aronovic, Housing the Miasses (1939); Ford, Sluass and Housrive (1936); Post, The Challenge of Housing (1938); Stone \& Denton, TNEC Rep., Towarai More Housing, Monograph 8 (1940); National Resources Planumi:g Eqno, Our Cities: Thetr Role in the National Econony (1937), and Housna tre Co:itra:uing Problear (1940); Miusford, The Culture of Citres (1938).

How late, compared with other civilized countries, the United States was in accepring this public responsibility, can be gleaned from Comment, Low-Cost Housing: $A$ Europeart Survey (1942) 37 ILL. L. REv. 167.

For a persuasive statement of housing standards based on fundamental physiological and psychological needs, see Asterican Public Henltr Ass'x, Cosmritree on Hygic. of Housing, Basic Principles of Healtheul Housing (2d ed. 1939).

5. To the citations in note 4 supra, add Schaffter, State Huustro Agencaes (1942); Wallace, Survey of Federal Legislation Affecting Privatc Home Firancing Since 1932 (1938) 5 LaW \& Contedrp. Prob. 481.

Ifention might also be made of the hundreds of relatively recent federal, regional, state, and local "planning agencies." See publications by the NatrowsL Resources Planning Board: National Resources Developarent Refort (1942), Regional. Planming (1938), The Future of State Planming (1938); and see Walker, The Planining Fuxction in Urban Gorerniment (1941).

6. 1 Cooley, Taxation (4th ed. 1924) \$87; 5 110QunLrn, Muntcipal ConfonaTions (2d ed. 1928) \$\$2323, 2324; MrcAllister, Public Purpose in Taxation (1930) 18 CaLIF. L. Rev. 137, 241; Nichols, The Mreaning of Public Use is the Law of Entincnt Domain (1940) 20 B. U. L. Rev. 615.

The term "public use" is frequently used interchangeably with "public purpose" by many present day judges and writers. Others, however, in conformity with what they conceive to be traditional legal usage, seek to confine "public use" to tests of eminent domain and "public purpose" to tests of taxing and spending. When dealing with governmental aid to private enterprises, courts have in general been more willing to expand "public use" and allow private interests to exercise eminent domain than they have been to expand "public purpose" and permit governmental units to make public funds available to such private interests in the form of a subsidy. For this distinction there is good reason; possibilities of abuse are obviously greater in the expenditure of public funds for private interests than in permitting such interests to aid themselves by eminent domain. When dealing with public undertakings, where all property is to be publicly owned and possibilities of private profit are excluded, there vould, however, scem to be no rational basis for making a distinction between tests for eminent domain and for taxing and spending. If the undertaking is a governmental responsibility, it would 
not admit of exact definition; it is of too high abstraction to give specific direction to a court which is asked to limit the power of another governmental branch to expend public funds, or to borrow money, or to exempt property from general taxation. Indeed its chief virtue is in its infinite expansibility, which has permitted judges to respond to changing public opinion as to the goals of a democratic society and to the changing political, social, and economic factors which condition the achievement of such goals.

Before 1850 the courts paid little attention to any of the functions assumed by local governments in managing local affairs. The prevailing judicial attitude seems to have been that the mere act of governmental assumption automatically endowed an activity with all necessary "public" character. It was only after countless hamlets in the nation had, during the period of frenzied railroad promotion, bankrupted themselves in order to induce railroad companies to run tracks their way, and had then appealed to the courts in an effort to avoid payment of their obligations, that a different attitude began to appear. In these cases of contested railroad subsidies the courts for the first time considered seriously the argument that every government sponsored activity is not automatically for a "public" purpose, and that governmental expenditures should be restricted to a severely limited class of "non-private" functions. ${ }^{\text {" A1- }}$ though this argument met with little practical success in these particular cases, its usefulness in furthering the laissez-faire economic philosophy of that time was soon recognized. In consequence, despite its rather shady origin, it shortly became one of the most useful legal tools in later nineteenth century attempts to curtail governmental activities which were alleged to compete with "private" enterprise.

As public needs and dominant social attitudes changed, however, the courts, to keep pace with such change, gradually discarded the laissesfaire criteria, which alone gave restrictive force to the new-found con-

seem absurd to deny any governmental powers which might contribute to the success of the undertaking. What point could there be, for example, in granting eminent domain to a municipal corporation for condemning the site of a public housing project and yet denying the power to expend public funds to pay for this site? Compare the opinion of the New York Court of Appeals in New York City Housing Authority v. Muller, quoted in the text, infra p. 48. In deference to the niceties of legal scholarship, however, since this article is concerned primarily with taxing and spending, the term "public purpose" will be used throughout.

7. The "first clear-cut sfatement of the doctrine" is found in the decision of Chief Justice Black of the Pennsylvania Supreme Court in Sharpless v. The Mayor of Philadelphia, $21 \mathrm{~Pa} .147$ (1853). For an excellent discussion of the origins and growth of the public purpose doctrine as a limitation on the taxing and spending power of government, see McAllister, Public Purpose in Taxation (1930) 18 CalIF. L. Rev. 137. For a similar history of the public use' concept in eminent domain, see Nichols, The Mcaning of Public Use in the Law of Eninent Domain (1940) 20 B. U. L. Rev. 615. 
cept. Thus, one by one, such "rules"8 as that, unless a natural monopoly existed, the field must be left to private initiative; that governments could assume only such functions as were vital to community existence and were not adequately provided by private capital; that the activity must be equally beneficial to every member of the community and must be open to use by all the people; $;^{9}$ and that any project which openly competed with private enterprises in the same field was necessarily private in character, were either covertly emasculated or openly repudiated by courts in those situations where obvious social needs called for judicial sanction of the governmental activity in question. ${ }^{10}$ As a result of these doctrinal changes, there has been such expansion of "public purpose" that today, despite its firm establishment in the standard legal vocabulary, it seldom is permitted actually to interfere with activities which the public clearly insists that its government assume. From the slow process of judicial itemization, specific functions of the greatest variety have emerged - in conformity with contemporary needs and conceptions of policy - as clearly public in character. ${ }^{11}$

Until June of this year, public housing projects, established under the USHA ${ }^{12}$ local authority plan to provide healthful homes for families of low income who cannot otherwise obtain such homes, seemed to have been irretrievably placed in this category of settled public purpose. Recent decisions by the highest courts, "liberal" and "conservative" alike, of

8. These "rules" are obviously loose, overlapping generalizations.

9. An irresponsible importation from the field of eminent domain, where it has also been largely discarded. See note 67 infra.

10. Jones v. Portland, 113 Me. 123, 93 Atl. 41 (1915), affd, 245 U. S. 217 (1917); Green v. Frazier, 44 N. D. 395,176 N. W. 11 (1920), affd, 253 U. S. 233 (1920) ; Standard Oil Co. v. Lincoln, 114 Neb. 243, 207 N. W. 172 (1926), off'd far curiant, 275 U. S. 504 (1927); Carmichael v. Southern Cosl \& Coke Co., 301 U. S. 495 (1937). See also Moxey, Is Gozcrmment Mcrchandising Constitutional? (1918) 52 ANr. L. REv. 215.

The most extensive "dilution of public purpose" is, of course, in the decisions sustaining direct municipal subsidies to private enterprises as a mode of inter-state or intermunicipal competition for industry. Albritton v. Winona, 181 Mliss. 75, 173 So. 799 (1938) (sophisticated opinion sustaining municipal building of factories for leasing to private interests). Cf. Carroll v. Cedar Falls, 231 Iowa 277, 261 N. W. 652 (1935); Fernandia v. State, 143 Fla. S02, 197 So. 454 (1940); Comment (1941) 9 Duke B. A. J. 15; Comment (1928) 41 Hanv. L. Rev. 775; Note (1938) 47 Yale L. J. 1412.

11. As, for example, street railroads, water works, light and power plants, gas worls, swimming pools, airports, and playgrounds. See 1 Cooney, TAxntros (4th ed. 1924) $\$ \$ 200-213$; 5 MIcQuillin, MIUnicipal CoRronitions (2d ed. 192\$) $\$ \$ 2325-2328$.

12. Now known, under the President's Exccutive Order of February 24, 1942, setting up the National Housing Agency, as the Federal Public Housing Authority (FPHA). EXEC. ORDER 9070, 7 FED. REG. 1529 (Feb. 26, 1942). For exposition of the changes, irrelevant here, effected by this order, see Weintraub and Tough, Fodcral Housing and World War II (1942) 1S J. of LANid \& P. U. Econ. 155. The old name (USHA) is retained throughout this article for the sake of clarity. 
twenty-three states ${ }^{13}$ specifically on the point, ${ }^{14}$ plus numerous decisions holding expenditures to be for a "public purpose" when for such activities

13. In re Opinions of the Justices, 235 Ala. 485,179 So. 535 (1938); Humplurey v. Phoenix, 55 Ariz. 374, 102 P. (2d) 82 (1940); Hogue v. Housing Authority of North Little Rock, 201 Ark. 263, 144 S. W. (2d) 49 (1940); I Houtsing Authority of Los Angeles County v. Dockweiler, 14 Cal. (2d) 437, 94 P. (2d) 794 (1939); The Moffat Tunnel Improvement District v. The Housing Authority of the City and County of Denver, 125 P. (2d) 138 (Colo. 1942); State e.x rel. Harper v. McDavid, 145 Fla. 605, 200 So. 100 (1941); State ex rel. Burbridge v. St. John, 143 Fla. 544, 197 So. 131 (1940), supplem. op., 143 Fla. 876, 197 So. 549 (1940); Marvin v. Housing Authority of Jacksonville, 133 Fla. 590, 183 So. 145 (1938) ; Williamson v. Housing Authority of the City of Augusta, 186 Ga. 673, 199 S. E. 43 (1938) ; Krause v. Peoria Housing Authority, 370 I1l. 35t, 19 N. E. (2d) 193 (1939); Edwards v. Housing Authority of City of Muncic, 215 Ind. 330, 19 N. E. (2d) 741 (1939) ; State ex rel. Porterie v. Housing Authority of New Orleans, 190 La. 710, 182 So. 725 (1938) ; Matthaei v. Housing Authority of Baltimore, 177 Md. 506, 9 A. (2d) 835 (1939); Allydonn Realty Corporation v. Holyoke Housing Authority, 304 Mass. 288, 23 N. E. (2d) 665 (1939) ; Laret Investment Co. v. Dickmann, 345 Mo. 449, 134 S. W. (2d) 65 (1939) ; Rutherford v. Great Falls, 107 MIont. 512, 86 P. (2d) 656 (1939) ; Lennox v. Housing Authority of Omaha, 137 Neb. 582, 290 N. W. 451, 291 N. W. 100 (1940) ; Romano v. Housing Authority of Newark, 124 N. J. L. 452, 12 A. (2d) 384 (1940) ; Wells v. Housing Authority of Wilmington, 213 N. C. 744, 197 S. E. 693 (1938); Dornan v. Philadelphia Housing Authority, 331 Pa. 209, 200 Atl. 834 (1938); MeNulty v. Owens, 188 S. C. 377,199 S. E. 425 (1938); Knoxville Housing Authority v. Knoxville, 174 Tenn. 76, 123 S. W. (2d) 1085 (1939); Housing Authority of Dallas v. Higginbotham, 135 Tex. 158, 143 S. W. (2d) 79, 130 A. L. R. 1053 (1940) ; Mumpower v. Housing Authority of the City of Bristol, 176 Va. 426, 11 S. L. (2d) 732 (1940) ; Chapman v. Huntington, W. Va., Housing Authority, 121 W. Va. 319, $3 \mathrm{~S}$. E. (2d) 502 (1939). In addition to these twenty-three decisions, the following cases contain at least a strong implication of tax exemption: Spahn v. Stewart, 268 Ky. 97, 103 S. W. (2d) 651 (1937); New York City Housing Authority v. Muller, 270 N. Y. 333, 1 N. E. (2d) 153 (1936). All of these state decisions are collected in Notes in 130 A. L. R. 1069 (1941) and 133 A. L. R. 365 (1941). For discussion, see: Nichols, Condemnation for Public Housing (1940) 5 Legal Notes on LocAl. Gov. 122; Comment (1937) 36 Mich. L. Rev. 275; Comment (1941) 26 MinN. L. Rev. 81; Note (1936) 45 Yale L. J. 1519; (1940) 8 Geo. Wash. L. Rev. 862; (1938) 87 U. of PA. L. Rev. 118; Keyseruing, Legal Problems in the Housing Fieid (National Resources Committee, Housing Monograph Series, No. 2, 1939) 42.

Forerunners to the above cited decisions, and expressing the same enlightencd judicial understanding of "public purpose," are First Municipality v. MLcDonough, 2 Rob. 244 (La. 1842); Veterans' Welfare Board v. Jordan, 189 Cal. 124, 208 Pac. 284 (1922); Willmon v. Powell, 91 Cal. App. 1, 266 Pac. 1029 (1928); Simon v. O'Toole, 108 N. J. L. 32, 155 Atl. 449 (1931), aff'd, 108 N. J. L. 549, 158 Atl. 543 (1932); Grcen v. Frazier, 44 N. D. 395, 176 N. W. 11 (1920), aff'd, 253 U. S. 233 (1920). See Robinson, Public Housing in Massachusetts (1938) 18 B. U. L. Rev. 83.

The New York courts have sustained the tax exemption of buildings and improvements erected by limited dividend companies, even though such companies allow, of course, a certain amount of profit to private enterprise. Roche v. Sexton, 268 N. Y. 504, 198 N. E. 420 (1935); Matter of Mount Hope Development Co. v. James, 258 N. Y. 510, 180 N. E. 252 (1932) ; Mars Realty Corp. v. Sexton, 141 Misc. 622, 253 N. Y. Supp. 15 (Sup. Ct. 1931).

It is worth noting that the much discredited United States v. Certain Lands in the City of Louisville, 78 F. (2d) 684 (C. C. A. 6th, 1935), which Mr. Russell (at 381, 
as gasoline filling stations, ${ }^{15}$ tourists' camps, ${ }^{10}$ public golf courses, ${ }^{17}$ ice plants, ${ }^{18}$ municipal celebrations, ${ }^{19}$ city bands, ${ }^{20}$ and opera houses ${ }^{21}$ (all of which might well be regarded from any conceivable point of view as far more questionable than housing), appeared so conclusive that the point was generally conceded to be one which present day courts would accept as axiomatic. ${ }^{22}$

In upholding the public character of USH.A-approved local housing projects, the courts of the twenty-three states mentioned above relied, either directly or vicariously by citation, upon the well documented facts that slum clearance and the provision of sanitary low-rent housing decrease danger of epidemics, raise general public health, reduce crime,

n. 3) cites as "holding that the federal government had no power to condemn land for low-rent housing projects because taking of land for such purpose was not a taling for a public use," has been rejected by the Tenth Circuit. Oklahoma v. Sanders, 94 F. (2d) 323 (C. C. A. 10th, 1938). Cf. Enenstern, op, cit. supra note 4, at 32; Corwin, Constitutional Aspects of Federal Hausing (1935) 84 U. of PA. L. KEv. 131; Comment (1911) 39 Mirch. L. Rev. 457.

14. This unanimity of decision is especially striking because of the substantial differences in the various constitutional and statutory provisions involved [e.g., In re Opinions of the Justices, 235 Ala. 485, 179 So. 535 (1938) (property exempt as property of municipal corporation); Marvin v. Housing Authority of Jacksonville, 133 Fla. 590, 183 So. 145 (1938) (project exempt as property for municipal purposes); Alumpower v. Housing Authority of City of Bristol, 176 Va. 426, 11 S. E. (2d) 732 (1940) (project exempt as property of political subdivision) ; Chapman v. Huntington, W. Va, Hous= ing Authority, 121 W. Va. 319, 3 S. E. (2d) 502 (1939) (project exempt as "public property"); Williamson v. Housing Authority of the City of Augusta, Georgiz, 185 Ga. 673, 199 S. E. 43 (1938) (project exempt both as "a purely public charity" and as public property); Krause v. Peoria Housing Authority, 370 Ill. 356, 19 N. E. (2d) 193 (1939) (project exempt as public charity)], and because usually starc dcrisis vas either of no assistance altogether or favored a conclusion contrary to that reached by the court. For example, see Allydonn Realty Corp. v. Holyoke Housing Authority, 304 IIass. 288,23 N. E. (2d) 665 (1939). Cf. Brammer v. Housing Authority of the Birmingham District, 239 Ala. 280, 195 So. 256 (1940); Dornan v. Philadelphia Housing Authority, $331 \mathrm{~Pa}$ 209, 200 Atl. 834 (1938).

15. Standard Oil Co. v. Lincoln, 114 Neb. 243, 207 N. W. 172 (1926), ofl'd fer curiana, 275 U. S. 504 (1927).

16. State ex rel. Mfinner v. Dodge City, 123 Kan. 316, 255 Pac. 387 (1927).

17. Booth v. Minneapolis, 163 Minn. 223, 203 N. W. 625 (1925).

18. Tombstone v. Macia, 30 Ariz. 218, 245 Pac. 677 (1926).

19. Schieffelin v. Hylan, 236 N. Y. 254,140 N. E. 689 (1923).

20. Goodnight v. Wellington, $118 \mathrm{Tex} 207,13 \mathrm{~S}$. W. (2d) 353 (1929).

21. See Egan v. San Francisco, 165 Cal. 576, 581-582, 133 Pac. 294, 295-296 (1913).

22. Compare Abrams, Book Review (1910) 50 Y YLE L. J. 361: "Dominating the whole issue in the dark days of 1934 was a question that now sounds as distant and forgotten as 'The Merry Widow': is public housing a public use for which public monies could be spent and private property acquired "?" See also B.uven, A Cirize:s's Guibz in Public Housing (1940) 35: "Any doubts as to the legality of legislation essential for slum clearance and low-rent housing have been completely dispelled . . ." 
cut juvenile delinquency, reduce immorality, lower economic waste by reducing health, police and fire protection costs, make better citizens, eliminate fire hazards, increase general land values in the vicinity, cut the accident rate, and prevent the cancerous spread of slums to uninfected areas. ${ }^{23}$ For the better achievement of such generally preferred events, these courts have insisted that non-profit public housing authorities should be accorded not only tax-exemption, but also all relevant and necessary governmental powers. This common jụdicial attitude was well stated in the first, and still leading, case of New York City Housing Authority v. Muller, ${ }^{24}$ which sustained a legislative grant of eminent domain to local public housing authorities. There the New York Court of Appeals announced in often-quoted words:

"The fundamental purpose of government is to protect the health, safety and general welfare of the public. All its complicated activities have that simple end in view. Its power plant for the purpose consists of the power of taxation, the police power and the power of eminent domain. Whenever there arises, in the state, a condition of affairs holding a substantial menace to the public health, safety or general welfare, it becomes the duty of the government to apply whatever power is necessary and appropriate to check it. There are differences in the nature and characteristics of the powers, though distinction between them is often fine . . . But if the menace is serious enough to the public to warrant public action and the power applied is reasonably and fairly calculated to check it, and bears a reasonable relation to the evil, it seems to be constitutionally immaterial whether one or another. of the sovereign powers is employed."

For the removal of such "substantial menaces" to the public health, safety and general welfare as slums, all of these courts have either expressly recognized or taken for granted the completely complementary character, in any effective program, of slum clearance and the provision of new low-rent housing. It is the demolition of unhealthful living conditions, not the mere physical razing of unhealthy buildings, that is the object of insistent public demand; such demolition cannot - because of the failure of private enterprise to furnish an adequate supply of healthful low-rent homes ${ }^{25}$ - be achieved without governmental provi-

23. The final consideration may not be as obvious as the others. For an excellent description of how slum areas blight, and eventually make slums of, adjacent arens, see WALKER, URBAN BLIGHT aNd Slums (1938) 17.

24. 270 N. Y. $333,340-341,1$ N. E. (2d) 153,155 (1936). Cf. Allydonn Realty Corp. v. Holyoke Housing Authority, 304 Mass. 288, 23 N. E. (2d) 665, 670 (1939).

25. Surveys have made it clear that families with incomes ranging not only from $\$ 600$ to $\$ 1,200$ per annum but considerably higher, and who can afford rentals of $\$ 10$ to $\$ 25$ per month, are not being adequately provided with safe and sanitary housing by private enterprise. See, for example, SEn. Rer. No. 933, 75th Cong., 1st Sess. (1937) 
sion of new housing facilities, within the reach of low-income families, to replace slum and substandard dwellings. ${ }^{20}$

In the light of this well-reasoned and almost overwhelming judicial precedent, two recent and surprisingly similar arguments that typical USHA local housing authority projects are not entitled to tax exemption would seem plainly untenable from the perspective of either law or policy. The first of these is set forth in an article on the "Tax Status of Public Housing" by Mr. Horace Russell in the June issue of the American Bar Association Journal. ${ }^{27}$ Starting from the convenient but unorthodox premise that even in the case of goz'wininent-ozined property "there would appear to be a constant presumption in favor of taxability," rebuttable "only by evidence of current use for non-tasable

$5,6,7,9$. Especially significant is the statement of the Senate Committce on Education and Labor in this Report (at 9) that:

"The actual results of the Federal Housing Administration's efforts to induce private capital into the low-rent housing field have bcen 43 projects with an average rent per roosin of \$13.\$2 per month. This rent level hardly serves families with incomes under $\$ 3,300$ per year-and such families comprised fourfifths of the total population even in 1929." (emplrasis supplied).

The hearings before the TNEC also indicate clearly that private enterprice has failed to provide adequately for families with incomes ranging from $\$ 600$ to $\$ 1,200$ per year and who can afford rentals of from $\$ 10$ to $\$ 25$ per month. These hearings show that $4,000,000$ dwellings in the United States are unfit for human habitation even by the lowest standards, and that, if lack of proper sanitary facilities be talien as a criterion, approximately a million and a half more must also be classed as substondard. They also show that, aside from the shortage already in existence, private enterprise is failing miserably to meet annual requirements, i.e.. the bare maintenance of housing facilities, fur non-farm families of low income. Thus, while 60,000 non-farm dwelling units to rent at $\$ 10$ per month were required in $193 \mathrm{~S}$ and 1939 merely to maintain the already inadequate supply of facilities for families with \$10-a-weel incomes, practically nu dwelling units of this nature were constructed by private enterprise in 1938. Out of the 136,000 nonfarm dwellings needed for families who can afford a \$10-to-\$20-3-month rontal, only $1 / 10$ of $1 \%$ of the necessary amount was provided; and of the 125,000 new dwelling units needed for families who can afford to pay a $\$ 20$-to-\$30-a-month rental, only $10 \%$ of the necessary number of dwelling units was provided by private enterprise. The testimony showed that substantially no building was being done which would be available for persons having an income of $\$ 1,500$ a year or less. It showed that, while $92 \%$ of the families in the United States had incomes of $\$ 2,500$ or less in 1935 , only $48 \%$ of the housing built on the average in 1930-37 was in that range. Hcarings before the Tcmporary National Economic Committec, 76th Cong., 1st Sess. (1939) Pt. 11, 4958-4965, 4975-4980, 5433, 5479. Compare Stone \& Denton, TNEC RLi., Towaris MI re Housing, Monograph S (1940) 21-29, 90; Enenstern, The Liw os Punlic Ilorst:ig (1940) 5; Post, The Challenge of Housing (1938) passin.

26. Merely to demolish slum-type dwellings, occupied by families for whom private enterprise cannot supply healthful homes, is at best to send these families to create new slums elsewhere.

27. Russell, Tax Status of Public Housing (1912) 28 A. B. A. J. 391 . Mr. Russell is General Counsel of the United States Savings and Loan League. For purposes of convenience, this article will be cited hereafter as Russell.

28. Id. at 383. 
purposes," ${ }^{29}$ Mr. Russell argues that the determination that public housing projects are used for charitable or public purposes must be established annually to entitle them to tax exemption for that year. From his repeated emphasis upon such phrases as "families of lowest income" and "very lowest, slum-level families," and from the whole pattern of his article, it is clear - though his language is nowhere completely explicit - that what Mr. Russell proposes as a criterion of "public purpose" in such annual reexaminations of public housing projects is the practically complete poverty of the tenants who are served. ${ }^{30}$ Thus, he sug-

29. Russell, 383.

30. The whole tone of the article, and the impression to be gained from his conclusions, is clearly that he objects to tax exemption of property serving others than the destitute. Thus, in his discussion of Krause v. Peoria Housing Authority, 370 Ill. 356, 19 N. E. (2d) 193 (1939), which held the property of the Peoria Housing Authority exempt as property "devoted exclusively to a charitable purpose" (370 Ill. 356, 367), Mr. Russell insists (at 383) that the "court stressed the point that the housing units in question were available only to families of the lowest income class" (emphasis supplied), wherens the court's phrase was simply "families of low income." It is possible, by scanning his language with especial meticulousness and by giving the most restricted meaning possible to his statements, to argue that his thesis is not that only projects serving the absolutely poverty-stricken should be tax exempt, but that any projects scrving those whom private enterprise is not providing with decent accommodations are entitled to exemption. But when he writes (at 384) that, "when any project caters to families above the lowest or slum-level income group," it supplies "a need which private facilities could fill at a price which one not in the lowest income group could afford to pay," he scems to assume that private enterprise is providing more decent accommodations at lower prices than the facts warrant. He offers no factual basis for this assumption, nor does he discuss the range of rentals or incomes among slum-dwelling families. He merely states (at 382) that rents in the public housing projects "range from about $\$ 10.00$ per month to about $\$ 25.00$ per month" and that dweiling units "are generally rented to tenants of good credit having a reliable income ranging from about $\$ 600$ to about $\$ 1,200$ per annum," and offers in contrast (at 384) an undefined (unless a reference, at 382, to tenants of "no income" or of "extremely uncertain income" is a definition) category of "lowest or slum-level income" groups. The clear implication is that urban families with an income of $\$ 600$ to $\$ 1,200$ a year can obtain decent housing without government help.

It seems unnecessary to belabor authorities to prove the complete unrcality of this assumption. To even the most casual observer it must be obvious that decent quartersdefining "decent" in terms of sufficient space, light, air and sanitary facilities to provide for living at a level above the sub-human-are not presently available (wholly apart from war conditions, which can only augment shortages and inflate prices for the future) at rentals of between $\$ 10$ and $\$ 25$ per month. Let Mr. Russell, or anyone else, spend a day in inspecting the quarters available to an average family of four at these rentals in any large city north of the Mason and Dixon line. Or let him approach any reputable building contractor in the same area and suggest that he build quarters in which he would be willing to house his family at a price which would permit profitable rental at a figure of $\$ 20$ per month, including heat. What he will see and what he will hear will be more convincing than any charts or statistics. The factors which condition this high cost of housing are too involved for exposition here, including, as they do, a disorganized, restraint-ridden construction industry, inflated urban land costs, regressive taxation, nonexistent or chaotic land-use "planning," and the entire home financing structurc. Suffice it to say that all of these factors, and many others, combine to make it impossible for 
gests that "the purpose of a housing project" continues "to be public only so long as it" performs "the function of eradicating slums by lifting families of lowest income out of such areas and placing them in modern housing units" and ceases to be public when it "ceases to provide for the very lowest, slum-level families" and "benefits only a small fraction of the general public, not of the lowest economic level." 31 Having already described existing public housing projects as "generally rented to tenants of good credit having a reliable income ranging from about $\$ 600$ to about $\$ 1200$ per annum" 32 and "built and operated upon a basis to provide the facilities, services and accommodations of the modern apartment or apartment hotel," ${ }^{33}$ Mr. Russell therefore conveys the notion that such projects are not for a public purpose since "Generally speaking, none of these projects have admitted tenants having no income, nor have they admitted tenants of poor credit, nor have they admitted tenants having the lowest income in the country nor have they admitted tenants of an extremely uncertain income." 34 How "public purpose" suddenly acquires such a definite, limited, absolutistic meaning, despite the great weight of popular, legislative, and judicial opinion to the contrary, is not made clear. But from such premises Mr. Russell easily concludes that public housing projects renting to tenants more prosperous than "the lowest" or "the very lowest slum-level families" are not entitled to tax exemption, and that any exemption granted them is "discrimination in favor of a class" and "imposes an extra burden on similar private activities not so exempt." 36

The second espousal of this anachronistic view, coinciding with the Russell theory in underlying concept as well as in time, is the recent five-to-two decision of the Ohio Supreme Court in Columbus MIetropolitan Housing Authority v. Thatcher, ${ }^{37}$ in which it was held that a

private interests profitably to produce adequate dwellings at a price within reach of the low income segment of our population. See note 25 supra. For an illuminating analysis of the entire construction industry, describing at least some causes of the high cost of housing, see Stone \& Denton. TNEC Rep., Toward Mloge Housrato, Monograph 8 (1940). See also TNEC Hcarings, of. cit. supra note 25.

It may be argued that, even though $\$ 600$ to $\$ 1,200$ income families now live in the slums, decent housing should be provided first for families of still lower income But a start had to be made somewhere, and exactly where it should be made would appear to be a question of policy for the legislature to determine. In any event, this is an argument not for eliminating local subsidy, but rather for increasing it.

31. Russell, 383 .

32. Id. at 382 .

33. Ibid.

34. Ibid.

35. Id. at 384.

36. Ibid.

37. 140 Ohio St. 38,42 N. E. (2d) 737 (1942). Judges Williams and Zimmerman dissented. Noted in 57 Asrerican CITY 76-77 (June, 1942). Hereinafter eited as the Colunzbus case. 
municipally controlled, typical USHA-qualified public housing project which admits tenants who can afford to pay rent is not entitled to tax exemption under the relevant Ohio statutes and constitutional restrictions.

The reasoning by which the Ohio Court, confronted by an apparent express declaration of tax exemption in the Ohio Housing Authority Act and by its own previous holding in State ex rel. Ellis v. Sherrill ${ }^{\text {ss }}$ that this statute was constitutional, was able to reach its result requires exposition at some length. The Constitution of Ohio provides, in part, in Section 2 of Article XII, that:

"Land and improvements thereon shall be taxed by uniform rule according to value ... and without limiting the general power, subject to the provisions of article I of this constitution, to determine the subjects and methods of taxation or exemptions therefrom, general laws may be passed to exempt . . . public property used exclusively for any public purpose . . . " (emphasis supplied).

The limiting provisions of Article I of the Ohio Constitution, referred to in the above section, include an "equal protection". clause. ${ }^{30}$ In its quotation of this section of the Constitution the Court italicized both this limitation and the word "exclusively." The general tax exemption law, enacted by the Ohio Legislature pursuant to this constitutional power, states that:

"Real or personal property belonging exclusively to the state or United States, and public property used for a public purpose shall be exempt from taxation." 40

Noting the absence of the word "exclusively" from the latter clatuse of this statute, and remarking that "the duty of this court to give a statute a constitutional construction, if possible, needs no citation," 41 the Ohio Court supplied the missing word on the ground that its inclusion was obviously the legislative intent. With this interpretation of the general statute established, the Court next examined the Ohio Housing Authority Act, which states that:

"All property, both real and personal, acquired, owned, leased, rented or operated by the housing authority shall be deemed public property for public use . . " 42

38. 136 Ohio St. 328,25 N. E. (2d) 844 (1940).

39. Article I, Section 2 of the Ohio Constitution reads:

"All political power is inherent in the people. Government is instituted for their equal protection and benefit, and they have the right to alter, reform, or abolish the same, whenever they may deem it necessary; and no special privileges or immunities shall ever be granted, that may not be altered, revoked, or repealed by the general assembly."

40. Onto Gen. Code Ann. (Page, 1938) \&5351.

41. Columbus case, 440.

42. Onio Gen. Code ANn. (Page, 1937) §1078-36. The substitution here of the word "use" for the word "purpose" is an example of the indiscriminate interchange re" 
Here again the Court noted the absence of the word "exclusively," but this time, reciting only "we assume that the Legislature was mindful of the constitutional limitation," ${ }^{43}$ it refused to supply it on the apparent, but not clearly articulated, ground that so to supply the word would create an express legislative declaration of tax exemption which (assuming - what the Court subsequently found - that property so "leased, rented or operated" was not held for a public purpose) would be unconstitutional. Thus, disregarding the obvious intent of the legislature, the Court was able to conclude that the omission by the legislature of the word "exclusively" in the statute (the legislature being presumed to know the constitutional limitations) showed that the Ohio Housing Authority Act was not intended to exempt all housing projects, complying with its requirements, from general taxation. What other purpose the legislature might have had in inserting in the statute the words "shall be deemed public property for public use," the Court did not attempt to say. ${ }^{* 4}$ In such manner, however, it fulfilled its duty, as it saw it, to give the statute a constitutional construction if possible, and also achieved the practical result of stripping the statute of all real effectiveness without the necessity of reconsidering, in express terms, whether or not it was constitutional. ${ }^{45}$

With the express legislative declaration of public purpose in the Housing Authority Act itself thus eliminated, the only remaining problem before the Court was that of whether projects constructed under the Act, and complying with all its requirements, were entitled to exemption under the general tax exemption statute recited above as "public property" used exclusively "for a public purpose." Such a determination, the Court assumed, was clearly judicial business requiring careful investigation. Since the Ohio Housing Authority Act expressly designates local authorities established in conformity with its terms as "bodies corporate and politic," the court did not question the fact that the property of such authorities was public property; but, like Mr. Russell, it insisted that general statutory tax exemption of even publicly owned property

ferred to above in note 6 . Eminent domain is provided for in the preceding section of the Act. OHIo Gen. CODE Axw. (Page, 1937) §107\$-35.

43. Columibus case, 440 .

44. Reading $\$ 1078-36$ in terms of the preamble to the statute contained in the first paragraph of $\$ 107 \$-30$, the final reference of the section to "public inspection" is inconsequential. Emphasis upon such reference would ignore common interpretation. $C f$. the opinion of the Att'y Gen. of Ohio, cited in the annotation to $\$ 1078-36$.

45. Section 2, Article IV of the Ohio Constitution provides:

“. . . No law shall be held unconstitutional and void by the supreme court without the concurrence of at least all but one of the judges, escept in the affirmance of a judgment of the court of appeals declaring a law umconstitutional and void ..."

The Columbus case was not an appeal from a judgment of the Court of Appeals. Reeall that two judges dissented. 
must be strictly construed. Then, in disregard of the necessary interdependence of slum clearance and rehousing in any practicable program, it distinguished between the "former" use of the property "(demolition of substandard dwellings on the project site) and the "present" use (lowrent housing), and concluded that while the physical clearance was being carried on the property was held for a public purpose and therefore tax exempt, but that after the project was completed and renting had begun, it could no longer be so classified. Grounding its decision firmly on Broom's Legal Maxims and Lord Coke, the Court here minced no words : ${ }^{40}$

"It seems to us clear that where dwellings are leased to family units for the purposes of private homes, the use of such dwellings is private and not public. Under Anglo-Saxon law and tradition, there is nothing more private than one's home. Broom's Legal Maxims, 9th Ed., 283, Semayne's Case, 5 Coke, 91, 77 Eng. Rep. R., 194. That every man's house is his castle has not yet been erased from our laws.

"Furthermore, a tax advantage equal to $\$ 3.13$ per month on home rental given to a selected few persons who are not paupers and who are not aged, infirm or without means of support is violative of the provisions of Section 2 of Article XII and Section 2 of Article I of the Constitution of Ohio [public purpose and equal protection requirements]. Such tax exemption would shift the tax burden to other home owners and taxpayers."

It emphasized testimony to the effect that the tenants must be able to pay the rents charged and that they were selected from substandard houses everywhere and not merely from the particular slums demolished. ${ }^{47}$ It was shocked, furthermore, to note that under the housing authority's substandard housing score sheet "a very large portion if indeed not a majority of the houses in this state could be declared substandard." 4 s

46. Columbus case, 442 .

Broom's maxim is: Domus sua cuique est tutissimum refugium. But even Semayne's Case states that, though "every man's house is his castle," in all cases where the King is a party the sheriff may break the house!

47. The Ohio Court's assumption is the same as that of Mr. Russell: that tenants who can afford to pay an average monthly rental, including heat, light, gas and water, of $\$ 18.25$ to $\$ 19.25$ per month (the scale of rents charged by the project in question) can get adequate living quarters in privately owned property and, hence, that there is no need for public housing projects. For demonstration of the lack of factual basis for this assumption, see notes 25 and 30 supra.

48. Columbus case, 442. Briefly, the Court emphasized the fact that there was evidence before the Board of Tax Appeals which showed that the general regulations prescribed by the local housing authority could be interpreted to permit admission of tenants who came from homes that were substandard only in the sense that they did not have inside water or bathroom facilities or electric lights. But there was nothing in the evidence to indicate that the tenants actually selected for the project did come from such dwellings. In other words, the Court based its decision not upon the facts, but upon the theoretical possibilities. 
In order to grasp the full practical effect which the Russell theory and the Ohio decision (hereinafter referred to jointly as the Ohio-Russell theory) could have on the entire USHA program, the only program of slum clearance and public housing which is at present effectively functioning, some further understanding of the purposes and structure of that program is essential. ${ }^{49}$

It must be realized at the outset that the USHA was designed to meet the need of those in our society who, though having some income, can not pay a sufficient rental to achieve decent, sanitary living quarters. Based on the fact that private industry, even when aided by government guarantees, cannot provide healthful housing at rents which the lowerincome-third of the population can afford to pay, the plan clearly recognized that direct subsidy in the form of a rental admittedly below the economic rent of the quarters provided was essential. It was realized that only by providing such quarters could the costly and disgraceful slums of our cities be eventually eliminated, and healthful living conditions provided for people now living in slum-type substandard houses. The fact can not be over emphasized that the program was never intended simply to provide free living quarters. ${ }^{50}$ It was an expression of the realization that there are grades of social need between abject poverty and plenty, and that those who need some help in order to achieve the basic necessities of life, and are able and willing to contribute the balance themselves, are as deserving of aid as those who can or will not contribute anything. That this principle was accepted and endorsed by the majority of the people is shown not alone by the enactment of the federal statute but also by the adoption by almost forty states of enabling statutes providing for the establishment of local housing authorities to put the principle in operation.

The plan set up to achieve this purpose can be briefly stated. The state enabling statute provides for the formation of local housing authorities as "public bodies corporate and politic," to cooperate with

49. For a more extended description see Tretter, Public Housing Finance (1941) 54 H.1Rv. L. Rev. 1325. See also Report of Conmittee on the Law of Housing from the Point of View of the Inzestor, Municipal I.aw Section, American Bar Association, Sept. $1,1941$.

50. Both the Senate and House Committee Reports on the United States Housing Act (upon which is based the present low-rent housing program, passed upon by the 23 courts) made it clear that: "The bill would serve the $\$ 600$ to $\$ 1,000$ a year family groups," and that: "Decent housing should be provided, of course, for the lonest income group that it is possible to reach. It must be recognized, however, that as long as any rent is to be charged in a project, the people who will occupy the dwellings must have some income . . . the tenants would . . . have to gay about 55 per cent of the usual economic rent." (emphasis supplied). Sex. Rep. No. 933, 75th Cong., 1st Sess. (1037) 13, 14; H. R. REP. No. 1545, 75th Cong., 1st Sess. (1937) 6. Relief frmilies can and do, of course, live in public housing projects; but their subsidy is from other than housing funds. 
the USHA. These local authorities, after proving that there are low income families in the locality who cannot afford decent housing built by private enterprise and whose needs will be met by the project, are eligible for a sixty-year loan from the USHA up to $90 \%$ of the project development cost. The remaining 10\% must be otherwise raised (a requirement designed to stimulate local initiative and interest), and up to the present time every local housing authority has raised at least this amount (and in some cases up to $85 \%$ of the project cost) by the sale of bonds to the general public. As security for such loans, the United States Housing Act provides for the pledging of annual contributions which the USHA contracts to pay to the local housing authority, and it is upon such contributions that private capital must primarily rely for security. The USHA pays these yearly subsidies, after the project is built and tenanted, to help bridge the gap between the total annual charges against the project and the rents which the tenants can afford to pay. These annual federal contributions must be supplemented by local contributions equal to at least one-fifth of the federal; and the combined contributions must be sufficient to insure rentals low enough to reach tenants of the specified income range. This annual local contribution, vital to any decentralized program, can be met either by direct grants or by tax exemption of the project; but because constitutional and statutory debt limitation provisions make it either impossible or difficult for municipalities to assume the necessary long-term obligations to make their contributions in cash, and because private capital also demands assurance of the permanence of the local contributions upon which the federal contributions are conditioned, all existing low-rent housing and slum clearance projects have received their local contributions in the form of tax exemption. ${ }^{.1}$ Finally, to make certain the "slum clearance" character of any specific program, the municipality is required to retire from use a number of slum-type substandard dwellings substantially equal to the number of new dwellings to be built.

It is apparent that the Ohio-Russell argument strikes at the very foundations of the above plan. It strikes at the basic requirements: (1) that at least some of the tenants must, if slums are to be cleared, make some contribution to their housing $\operatorname{cost}^{52}$ and (2) that the munici-

51. Cooperation agreements with many cities provide, however, for annual payments in lieu of taxes, and a general plan has been worked out, by the local authoritics and the USHA, whereby all available excess income from rentals is to be proportionately divided between the local and federal governments so as to reduce both the local taxexemption subsidy and the federal cash subsidy.

For this and other specific information, the writers are indebted to officials of the FPHA (formerly the USHA).

52. By an increase of subsidy, by new economies of operation, and by use of "graded" rents, it may hereafter become possible for public housing atthorities to serve the abso. lutely indigent; but under even the most hopeful anticipations of the future-if slums 
pality sponsoring the project, and receiving substantial federal assistance therefor, must raise part of the original cost from sources other than the federal government and must make continuing contributions partially to match the federal annual contributions. Thus the practical effect of the application of this theory is obviously to jeopardize at its inception a social program subscribed to by both the federal government and well over two-thirds of the states, and to which public and private funds and credit approximating a billion dollars have already been irrevocably committed. Especially close scrutiny of this argument and its possible effects would seem, therefore, to be of urgent importance.

It is in its disinterment of long-buried criteria of "public purpose" that the Ohio-Russell theory is, as has been indicated above, most completely out of step with contemporary social, political, and legal trends. The irrelevance of "Anglo-Saxon law and tradition" that, for purposes of repelling invaders, "every man's house is his castle," to the question of whether American municipalities can today subscribe one-fifth of the subsidy necessary to clear slums and provide healthful housing for the low-income third of their population, scarcely needs emphasis. ${ }^{\text {E3 }}$ Even if there had been no previous decisions specifically determining the status of such public housing projects, the criteria here adopted to test the validity of their tax exemption would be untenable today in the light of the long line of decisions which have so greatly extended the content of the term "public purpose" in order to enable municipalities the country over to engage in a wide range of activities in the interests of public

are to be cleared on an appropriate scale-some tenants must, contrary to the OhioRussell theory, be able to pay some rent.

53. The ambiguous middle (or reification of disparate meanings) in the Ohio Court's syllogism should be obvious. The argument runs: under "Anglo-Sason law and tradition," for purposes of repelling invaders, "nothing [is] more private than one's home"; public housing projects contain homes; therefore, for purposes of determining tax exemption, public housing projects must be "private."

More than half a century ago, when dealing with a much more questionable activity, the New Hampshire Court, with Judge Ladd sneaking, refused, in Perry v. Keene, 50 X. H. 514, 535 (1876), to be impressed by a similar argument:

"To say of a railroad corporation that it is a private corporation, and therefore the construction of a railroad is a private purpose, seems to me, in truth, no more logical, if less absurd, than to say of any officer or agent of the state,- $\mathrm{He}$ is an individual, with all of the private interests and private associations of other citizens; therefore the purpose of his office and all of his official acts is private... If the purpose is public, it makes no difference that the agent by whose hand it is to be attained is private."

Courts do not have to hold, as Mr. Russell suggests (at 3841, that a charity is "anything which benefits mankind" or that a public use is "anything which serves the general welfare" in order to sustain public housing projects. All they need to hold is that it is a public purpose for the government to supply healthiul homes to that portion of the population which cannot otherwise obtain such homes because private enterprise has failed to supply them at a price that they can afford to pay. 
welfare. ${ }^{54}$ It happens that Ohio itself had previously been in the very forefront of jurisdictions thus holding municipal projects valid as serving a public purpose even though the services of such projects were furnished only on a fee basis and hence were available only to those able to pay. As early as the 1890's the Ohio Court in the Toledo Gas cases held that a municipal gas works was sufficienty endowed with a public purpose to justify both the expenditure of tax funds for its creation ${ }^{60}$ and the exemption of its property from taxation, ${ }^{50}$ and these same cases have since been considered as among the leading cases on the now generally accepted extension of the public purpose concept to include activities of the class commonly termed "public utilities." Fr From the perspective of these decisions, made some fifty years ago, it is diffictilt to see what consistent policy the present Ohio Court, functioning in a modern climate of opinion and presumably conditioned by contemporary conceptions of the judicial function, can hope to implement in now holding that the services supplied by the Columbus Housing Project are not endowed with a public purpose merely because the services of such project are not confined to paupers and theoretically compete with private enterprise. ${ }^{58}$ It requires a strange logic to reconcile cases

54. See notes $10,11,13$, and 15-21 inclusive silpra.

55. State $e x$ rel. Att'y Gen. v. Toledo, 48 Ohio St. 112, 26 N. E. 1061 (1891).

56. Toledo v. Hosler, 54 Ohio St. 418, 43 N. E. 583 (1896).

57. 38 OHIo JURISPRUDENCE (1935) $\$ 32$, p. 760 . For the general acceptance of "public utilities" as for a public purpose, see 5 McQunlins, Munctral Corroratrons (2d ed. 1928) §§ 1923-1930.

The situations in which the Ohio Court has subsequently held invalid governmental expenditures or tax exemption for government-owned property as not for a public purpose have been so extreme that they clearly cannot be considered as reflecting a policy opposed to the Toledo Gas cases. The only such cases which extensive research has rcvealed are the following: Adams v. Nemyer, 54 Ohio St. 614, 46 N. E. 1154 (1804) (statute authorizing municipal bond issuance to finance the purchase of land and buildings for manufacturing purposes, held invalid) ; Cincinnati v. Lewis, 66 Ohio St. 49, 63 N. E. 588 (1902) (see note 83 infra) (rural land purchased by city for a waterworks which was never erected, and subsequently rented as a farm, held not entitled to tax excmption); Auditor of Lucas County v. State ex rel. Boyles, 75 Ohio St. 114, 78 N. E. 955 (1906) (use of tax funds to provide quarteriy pensions for needy blind, held invalid, since institutions already provided for their care); State e.x rel. Toledo v. Lynch, 88 Ohio St. 71, 102 N. E. 670 (1913) (use of tax funds to support a municipal motion picture theatre, held not use for a public purpose); Cincinnati v. Harth, 101 Ohio St. 344, 128 N. E. 263 (1920) (authorization of municipal expenditure of tax funds for restoration or repair of roadbed of privately owned street railway company, held invalid); Cleveland v. Ruple, 130 Ohio St. 465, 200 N. E. 507 (1936) (use of municipal exhibition hall for carrying on a general parking garage business, held not for a public purpose, although its use for parking of municipal vehicles, for the cars of municipal employees, and for general parking on a fee basis for the convenience of patrons of adjacent public hall and stadium, was held to be permissible).

58. That there is no competition, see notes 25 and 30 supra. That if there were competition, it would be irrelevant, see note 10 supra. See also Alabama Power Co. v. 
holding that the provision of conveniences for any home in a city is for a public purpose, with a holding that the provision of the home itself, for people who would otherwise be forced to live in dwellings which lack even adequate sanitary facilities, is not for such a purpose.

It must, furthermore, be remembered that the Ohio-Russell restrictive definition of "public purpose" is resurrected for application, not to a new and judicially untried type of project, but to a local activity already tested and found valid, without a single decision to the contrary, by the highest courts in twenty-three states. ${ }^{69} \mathrm{Mr}$. Russell is so bold as to suggest that the "question of the tax status of public housing based upon the facts of the present use of public housing projects is yet to be decided," ${ }^{60}$ and blithely disposes of this line of authority with the conclusion that "all such cases have proceeded upon either an assumed

Ickes, 302 U. S. 464 (1938) (holding damage suffered by existing power distributors as a result of competition from municipal power plants erected with federal aid to be damnzum absque injaria, giving such distributors no standing to contest the constitutionality of the Act making such aid available to municipalities.)

The question of whether or not the public housing program harms private enterprise has been well answered in Bauer, A Citizex's Guide ro Public Housravg (1940) 70:

"In the first place, only a very small element in the housing process is actually 'public.' The initiative of the local authority is a sort of catalytic agent which stimulates all kinds of profitable enterprise within ordinary private channels. As the New York Times pointed out in a recent editorial:

‘. . private capital takes part by investing, private owners by selling land, private architects and contractors by designing and erecting buildings, private manufacturers by making and selling materials, private artisans by doing the work Government steps in only to lend money, to see that the work is well done and to contribute a large enough subsidy to guarantee low rents." "

Miss Bauer then documents the well known fact that, even with the aid of the FHA, private industry has not been able to produce buildings within the reach of the lowerincome half of the population.

The fact is that the only competition which the public housing program offers to private enterprise is a very desirable competition with the landlords of slums whose properties should have long since been vacated and demolished under the police power. Imagine a vendor of rotten meat complaining about competition from a government "relief" agency dispensing fresh meat across the street!

It is interesting to note, furthermore, that the "private" real estate people do not raise any bitter objection to, or deny the "public purpose" of, the federal government's guarantees of private investment through, for example, the FHA and the Federal Savings and Loan Insurance Corporation. Crcdit is just as much a part of the whole institutional structure which supplies homes as is building or renting. Surely in its assumption of private credit risks the government is "competing" with private enterprise! The truth is, of course, as one of the writers has elsewhere tried to indicate (ArcDougal, Bools Review (1941) 54 HARv. L. REv. 526, 529) that "the increasing physical interdependence of all our land uses and the economic interdependence of all our activities centered about land have made the classic dichotomy between "public' and 'private," at least in so far as housing is concerned, "not only fruitless but positively harmful."

59. See note 13 supra.

60. Russell, 384. 
or a proven state of facts to the effect that the property of the authority in question was held for a charitable or public purpose." 01 He adds that "should this state of facts be challenged in a case involving an authority with tenants of substantial income, the long line of cases tpholding the tax-exempt status of other authorities would not be a precedent." ${ }^{2}$ In view of the fact that most of these twenty-three courts were dealing with state housing statutes which specifically provicle for the housing, not of paupers, but of people of moderate income who cannot afford decent housing, ${ }^{63}$ this conclusion is, to say the least, a bit startling. It may be presumed that the courts read the statutes whose validity they were determining. ${ }^{64}$ The Ohio Court, at least, does not affirmatively support this charge of judicial irresponsibility; it merely ignores the other state decisions without making any attempt to distinguish them. By such silence, it appears to stand only on the technical ground that the decisions of courts of other jurisdictions are not controlling on an Ohio court. The Court does not, however, make it clear why housing policy should vary so greatly in Ohio or why it should be so oblivious to the policy considerations found persuasive by all other courts.

61. Ibid.

62. Ibid.

63. Most Housing Authorities Laws provide that rentals may be fixed so as to produce revenues which (together with all other available moneys) will be sufficient to pay debt service, operating and maintenance costs, administrative expenses, and to create debt service reserves. Also, by express provision, most of these Laws permit tenants who have, and only such tenants as have, aggregate annual incomes not in excess of five (in the case of larger families, six) times the annual rental. Most Housing Authorities Laws further provide for tenancy by persons of "lozv income" and define such persons merely as persons who lack the amount necessary to enable them, without financial assistance, to live in decent, safe, and sanitary dwellings without overcrowding. Sec for example Arizona Municipal Housing Law, Laws 1939, c. 82, $\$ \$ 3,9,10$; Arkansas Housing Authorities Law, Act 298 of 1937, as amended, $\$ \$ 3(\mathrm{k}), 9$, 10; Georgia Housing Authorities Law, Act 411 of 1937 , as amended, $\$ \S 3(j), 9,10$; Maryland Housing Aulthorities Law, Laws 1937, c. 517, as amended, $\$ 1(3)(\mathrm{j}), 1(9), 1(10)$; Mississippi Housing Authorities Law, Laws 1938, c. 338, as amended, $\S \S 1(k), 7,8$; Oregon Housing Authorities Law, Laws 1937, c. 442, as amended, $\S \S 3(j), 9,10$; Pennsylvania Housing Authorities Law, 1937, Pub. L. 955, as amended, $\$ \$ 3(0), 12,13$; Washington Housing Authorities Law, Laws 1939 , c. 23 , as amended, $\$ \$ 3(j), 9,10$. These provisions clearly indicate that the legislatures contemplated tenants who might not be in the patuer class or whose income would not be extremely uncertain.

64. These courts have, in fact, been explicit in indicating their realization that the projects must serve families whose income Mr. Russell apparently would consider as "substantial." Housing Authority of the County of Los Angeles v. Dockwciler, 14 Cal. (2d) 437, 461, 94 P. (2d) 794, 806, 807 (1939); Williamson v. Housing Authority of the City of Augusta, Georgia, 186 Ga. 673, 677, 199 S. E. 43, 47 (1938); Allydonn Realty Corp. v. Holyoke Housing Authority, 304 Mass. 288, 295, 23 N. E. (2d) 665, 668, 669 (1939); In re Brewster Street Housing Site in the City of Detroit, 291 Mich. 313, 339, 289 N. W. 493, 503 (1939) ; Chapman v. Huntington, W. Va., Housing Authority, 121 W. Va. 319, 326, 3 S. E. (2d) 502, 506 (1939). 
In its contention that tax exemption for low-rent housing projects is a denial of "equal protection," the Ohio-Russell theory defies, still again, any reasonable comprehension in terms of contemporary economic realities and judicial precedent. This contention underlies the reasoning of the entire Russell article and is expressed by the Ohio Court in its brief statement that a tax advantage "given to a selected few persons who are not paupers and who are not aged, infirm or without means of support is violative of the provisions of . . . Section 2 of Article I of the Constitution of Ohio." ${ }^{\text {65 }}$ But neither Mr. Russell nor the Ohio Court attempts to give the argument any, much less a persuasive, meaning. ${ }^{68}$ Admittedly part of the cost of any such project, whether supplied by tax exemption or more direct municipal subsidy, must be borne by the body of local taxpayers. Admittedly such projects must benefit those who cannot otherwise afford healthful housing in a somewhat greater degree than those who are fortunate enough to be able to provide their own decent living quarters - although no one would argue that the resulting elimination of slums does not benefit everyone in the community. But in terms of either policy or of well-settled judicial precedent, it is difficult to see how a contention that such exemption violates the equal protection clause, merely because its immediate benefits are not distributed equally among the income earners of the population, ${ }^{67}$ can be seriously advanced today. One might as well argue

65. Columbus case, 442.

66. The case of State ex rel. Struble v. Davis, 132 Ohio St. 555, 9 N. E. (2d) 684 (1937) which the Ohio Court cites in its syllabus, held valid the exemption for certain periods of the property, other than real estate used for railroad purposes, of interurban railroad companies. It is somewhat difficult to see how such a decision can be extrapolated into authority for a holding that a low-rent public housing project violates the equal protection clause of the Ohio Constitution.

67. It may be objected, invoking the legal syntax on a higher level of generalization, that the Ohio Court is merely holding any "classification unreasonable" which includes other than paupers. But by drawing the line with paupers and hence excluding any portion of the population beyond the pauper-line, the Court is in effect holding that any classification which includes a part, but not the whole, of the income earning population is unreasonable.

This all-or-nothing attitude, for determining "equality" or "reasonableness of classification," may have its roots in a now generally repudiated test-availability of use for the entire public-for determining the validity of exercises of the power of eminent domain. The present impotence of that test even in eminent domain is vell illustrated by a long line of decisions holding projects actually benefiting only a single "entity" to be for a public use. Thus the condemnation of a right of way for a logsing railroad to serve a single company has been upheld [Goose Creek Lumber Co. v. White, $219 \mathrm{Ky}$. 739,294 S. W. 494 (1927) ]; a right of way for an aerial bucket line has been held validly granted to a mining company [Strickley v. Highland Boy Gold Mining Co., 200 U. S. 527 (1906)]; condemnation for an irrigation system primarily benefiting a single land owner has been sustained [Fallbrook Irrigation Dist. v. Bradlcy, 164 U. S. 112 (1896)]; the provision of a right of way across neighboring land for the enlargement of an individual's irrigation ditch has been upheld [Clark v. Nash, 198 U. S. 361 
that all of the tax money collected from the Rockefellers, the Morgans, and the Mellons should be returned to the Rockefellers, the Morgans, and the Mellons, or that all of the tax money collected from Wall Street should be spent within the area of Wall Street. If unequal distribution of benefit alone were sufficient to invalidate either a tax or a tax exemption measure, every such measure would fall, since all stich meisures necessarily contemplate a benefit to some members of a community which is not shared to the same extent by all other members. Present day courts, recognizing this fact, have been almost unanimous in rejccting such an argument if the benefited class is not arbitrarily selected, and if the purpose in other respects serves the general public welfare. ${ }^{08}$ Excellent summary is offered by the Georgia Supreme Court in disposingr of this same argument in Williamson v. Housing Authority of Augusta:"ü

"It might also be claimed that the actual benefits derived from maintaining the Georgia Academy for the Blind are limited to blind children . . . or that adults are denied the actual benefits of the public school system because the schools are maintained only for children between certain ages . . . It is no violation of the constitutional guaranty here invoked for the State to provide direct benefits for a certain group, to the exclusion of other citizens, unless done by arbitrary standards. The governing authorities were well justified in limiting to those of moderate income the benefits of

(1905)]. Adequately summing up the state of authority are the words of Mr. Justice Holmes in Mt. Vernon-Woodberry Cotton Duck Co. v. Alabama Interstate Power Co., 240 U. S. 30, 32 (1916): "The inadequacy of use by the general public as a universal test is established." See also MacAllister, Public Purpose in Taxation (1930) 18 CAt.rF. L. REv. 241, 243-244; Nichols, The Meaning of Public Use in the Law of Entincm Domain (1940) 20 B. U. L. Rev. 615, 618-624; Note (1936) 45 YALE L. J. 1519, 1522.

Mr. Justice Crouch, speaking for the New York Court of Appeals in New York City Housing Authority v. Muller, 270 N. Y. $333,342,1$ N. E. (2d) 153,155 (1936), stated in connection with the concept of public as distinguished from private use:

"Use of a proposed structure, facility, or service by everybody and any-

body is one of the abandoned universal tests of a public use." (Citing numerous cases).

See also Dornan v. Philadelphia Housing Authority, 331 Pa. 209, 200 Atl. 834 (1938).

68. Fallbrook Irrigation Dist. v. Bradley, 164 U. S. 112 (1896); Carmichad v. Southern Coal and Coke Co., 301 U. S. 495 (1937). For state decisions rejecting this same argument in cases involving state housing statutes, see particularly Humphrey v. Phoenix, 55 Ariz. 374, 102 P. (2d) 82 (1940); Hogue v. Housing Authority of North Little Rock, 201 Ark. 263, 144 S. W. (2d) 49 (1940); Housing Authority of Dallas v. Higginbotham, 135 Tex. 158, 143 S. W. (2d) 79 (1940); Edwards v. Housing Authority of City of Muncie, 215 Ind. 330, 19 N. E. (2d) 741 (1939); Spahn v. Stewart, $268 \mathrm{Ky} .97,103 \mathrm{~S}$. W. (2d) 651 (1937).

It should be observed that no showing has ever been made that the "classification" of people to be housed under the USHA local authority plan is unreasonable. Taking into consideration what recent inventories have shown to be the state of housing conditions in this county, it is difficult to see how such a showing could be made.

69. 186 Ga. $673,677,199$ S. E. 43,47 (1938). 
the legislation under discussion. The statute makes a classification and states the basis thereof, which cannot be said by this court to be unreasonable."

The next major difficulty of the Ohio-Russell theory is that, in its offhand rejection of express legislative declarations of public purpose, without factual investigation adequate to show the unreasonableness of such declarations, it completely reverses contemporary notions of the relative functions of judiciary and legislature. Most courts, recognizing that "it is not the function of a court to determine whether the public policy that finds expression in legislation of this order is well or ill conceived,"70 and that proper respect for a coordinate branch of the government requires that all reasonable doubts about the constitutionality of a statute be resolved in its favor, ${ }^{71}$ have sought strenuously to give effect to legislative declarations of public purpose, especially in the case of government owned projects. ${ }^{72}$ This general principle of judicial humility has seldom been better stated than by Judge Ladd of the New Hampshire Supreme Court in a famous case upholding municipal subsidy of a private railroad ${ }^{\mathbf{7 3}}$

"Enough has been said to show the delicate nature of the task imposed upon the court when they are called upon to revise the judgment of the legislature in a matter of this description . . . because the rule to be applied is furnished, not so much by the law as by those general considerations of public policy and political economy to which allusion has been made. I do not deny the power and duty of the court, when private rights of property are in question, to settle those rights according to a just interpretation of the constitution; and the discharge of that duty may involve a revision of the judgment of the legislature upon a question which,

70. The quoted words are those of MIr. Justice Cardozo, spealing for the Court, in Williams v. Mayor and City Council of Baltimore, 289 U. S. 36, 42 (1933) (Maryland statute, exempting from taxation the property of a specific railroad, sustained).

71. This presumption is of course as old as the judicial power to declare statutes invalid. For discussion see Hamilton and Braden, The Special Compelenee of the Sispreme Court (1941) 50 YaLE L. J. 1319 passim. A recent leading case is O'Gorman v. Hartford Fire Ins. Co., 282 U. S. 251 (1931), where Mrr. Justice Brandeis insisted upon a "factual foundation of record," showing inappropriateness of remedy or nonexistence of assumed evils, before a statute exercising the police power could be held unconstitutional. No policy reason exists for distinguishing exercises of the tax or spending power.

72. Green v. Frazier, 253 U. S. 233 (1920) ; Jones v. Portland, 113 Me. 123, 93 All. 41 (1915), aff'd, 245 U. S. 217 (1917); Humphrey v. Phoenis, 55 Ariz. 374, 102 P. (2d) 82 (1940); Hogue v. Housing Authority of North Little Rock, 201 Ark. 263, 144 S. W. (2d) 49 (1940) ; Housing Authority of the County of Los Angeles v. Dodsweiler, 14 Cal. (2d) 437, 94 P. (2d) 794 (1939).

73. Perry v. Keene, 56 N. H. 514, 533 (1876). Though this particular case dealt with a subsidy to a private railroad, Judge Ladd's reasoning is a forliori applicable to statutory subsidies to public authorities. 
like this, partakes more or less of a political character. But before the court can reverse the judgment of the legislature and the executive, and declare a statute levying or authorizing a tax to be inoperative and void, a very clear case must be shown."

It has been the custom of all courts, even when guillotining legislation, to pay at least verbal deference to this principle. Yet Mr. Russell ignores it entirely, unless his implication that the legislators who included express declarations of public purpose in their housing statutes did not lnow or did not mean what they were saying can be considered as sufficient treatment. The Ohio Court, though it does in the Columbus case profess a duty "to give a statute a constitutional construction, if possible," "14 invokes the premise to justify its giving a meaning - that tax exemption was not intended - to the Ohio Housing Authority Act contrary to what most people had regarded as a clearly expressed legislative intent. It nowhere subscribes to the premise that, assuming the interpretation which most objective observers would give the statute, every reasonable doubt must be resolved in favor of its constitutionality as so interpreted; on the contrary, to rationalize its own peculiar interpretation, it assumes almost without argument, certainly without the requisite factual showing, that the statute, as commonly interpreted, would be unconstitutional. By such open legerdemain the Court was able to substitute its own outmoded laissez-faire economic notions for the policy considerations expressed by the people through their legislative representatives.

Even assuming, however, that express legislative intent to provide tax exemption for USHA-qualified housing projects is to be ignored, the Ohio-Russell theory is still forced to dispose of general tax exemption statutes which provide, as did the Ohio statute, for exemption of "public property" held for "public purposes." This it achieves only by continuing its policy of going contra to what is elsewhere regarded as settled law and policy. It adopts the strange position that such general statutory exemptions are to be strictly construed even for public property. The proposition that tax exemptions are to be construed strictly is, when put in proper context, orthodox enough. But the Ohio Court's addition of the statement that it sees "no reason for a distinction being made in the case of publicly owned property" (citing cases involving private property in support of its position) ${ }^{75}$ is certainly contrary to the

74. Columbus case, 440 .

75. Columbus case, 440. The citations given by the Court are Lce v. Sturges, 46 Ohio St. 153, 19 N. E. 560 (1889) (taxability of privately owned shares of railroad and telegraph company stock); In re Taylor's Estate, 139 Ohio St. 417, 40 N. E. (2d) 936 (1942) (taxability of a bequest to a society whose sole object was to encourage wider circulation of the Bible); and Cullitan v. Cunningham Sanitarium, 134 Ohio St. 99, 10 N. E. (2d) 205 (1938) (taxability of a privately owned sanitarium claiming exclusive use for a charitable purpose). 
generally accepted rule which holds that, once property is admitted to be public, the burden of clearly proving that it does not fall within an exemption provision rests on officials attempting to enforce taxation. ${ }^{70}$ The courts have found little sense and much waste of administrative effort in a governmental unit's merely transferring money from one pocket to another ${ }^{77}$ It is clearly sheer folly for a local community, after it has assumed the financial burdens of a low-rent housing project, to seek to charge itself with either taxes, or the cost of collecting taxes, on project property. What public purpose could be served by requiring such intramural buckpassing is difficult to see; even the most "strict" construction of general exemption statutes should preclude it. Yet Mr. Russell disposes of both policy and precedent by stating flatly: "The ownership of the property by a religious, educational, charitable or public body is beside the point." 78

Nor does the emphasis of the Ohio-Russell theory upon tense or time add persuasiveness to its dubious and eccentric presumption about the taxability of publicly owned property. The argument, as the Ohio Court puts it in the Columbus case, is that the proper question is not whether the property of a public housing authority was (presumably while the buildings were being erected) exempt as public property being used

76. See Baker, Tax Exemption Statutes (1929) 7 TEx. L. Rev. 385, 401:

"The reasons given for the rule of strict construction do not apply to the exemption of public property. It may be said that it is contrary to the policy of the state to exempt the property of individuals from tasation and that "tazistion is the rule, exemption the exception.' But it would seem that the state's policy would be to exempt its own property, and the burden of proof falls upon the officials attempting to enforce the tax, once it is admitted that the property is public property." (Citing cases).

Compare Stimson, Exemption of Publicly Owned Property from Taration (1934) 8 U. of Cin. L. Rev. 32; Comment (1935) 44 Yale L. J. 1075, 10S7; (1936) 35 Mrcu. L. REv. 172.

77. This attitude on the part of the courts was well summed up in In re Hamilton, 148 N. Y. 310,42 N. E. 717 (1S96). Speaking of publicly owned property, the court said:

"The end and purpose of all taxation is to raise revenue for the purpose of defraying the expenses of government, and since no revenue could be raised by imposing taxes on property owned by the state itself, or by any of its political divisions, such property is in no just or practical sense the subject of taxistion. It is never supposed to be included in the terms of any law providing for the imposition of taxes, however general it may be, not because it is exempt, in the sense in which that term is generally understood, but for the reason that, in the nature of things, it never was, and never can be, taxable."

In fact the rule, as stated in some jurisdictions, is that the legislative purpose to impose a tax on publicly owned property is never to be implied, and, unless the purpose to tax is clearly expressed, it will be presumed not to be intended. See Irb re Opinions of the Justices, 235 Ala. 485, 179 So. 535 (1938); Housing Authority of Los Angeles County v. Dockweiler, 14 Cal. (2d) 437, 94 P. (2d) 794 (1939).

78. Russell, 384. 
exclusively for public purposes, but rather whether such property is presently used exclusively for any public purpose. Mr. Russell's question, as has been indicated above, is whether the project has ceased to lift "the very lowest, slum-level families" 70 out of slums and has begun to cater to families "above the lowest or slum-level income group." 80 So much emphasis on tense or time - or, more accurately, the changing functions of a housing project - completely ignores what must be the necessary interdependence of "rehousing" and "slum clearance" in any comprehensive and effective program. ${ }^{81}$ Furthermore, reiteration of the word "exclusively," though the Ohio Court devotes much attention to it, adds no meaning to constitutional provisions like those of Ohio. The word is surplusage; ${ }^{82}$ even if it is not included, it is implied. It can be conceded that the purpose must be exclusively public in order to justify tax exemption. ${ }^{83}$ It can be further conceded that a

79. Russell, 383.

80. Russell, 384.

81. This interdependence was clearly recognized by the Ohio Court in its earlicr opinion in State ex rel. Ellis v. Sherrill, 136 Ohio St. 328, 331, 25 N. E. (2d) 844, 845 (1940). The Court enumerated the purposes of the United States Housing Act of 1937 in the following words:

"(1) the eradication of so-called slum areas . . . and (2) as a concomitant thereof, the furnishing of low-rent dweilings to families of low incomes." (cmphasis added).

The Court then went on to say:

"An examination of the evidence presented in the pending case shows on the whole a carefully conceived and balanced plan to abolish selected slum areas in the city of Cincinnati and to provide low-rent dwelling units within the municipal limits for families of low incomes, in general conformity with the purpose and design of the controlling legislation.

"If a plan as formulated by a local authority comes within the purview of the housing act and meets the approval of the National Housing Authority, whereby it is willing to lend federal funds in furtherance thereof, a court may not interfere."

82. 1 COOLEY, TAXation (4th ed. 1924) §174.

83. See 2 id. at $\$ 685$ :

" 'Exclusively' used, according to the better considered decisions, means the primary and inherent use and does not preclude such incidental uses as are directly connected with, essential to, and in furtherance of, the primary use."

The Ohio Court was not the only judicial body to be confronted with the words "exclusively for a public purpose" in a constitutional provision limiting the legislative power to tax. The Constitutions of Arkansas, Florida, Tennessee and South Carolina, for example, contain the same words. Yet the courts of these states, properly interpreting the meaning of these words and understanding the true nature of public housing projects, had no difficulty in finding that such projects unquestionably qualified under such words. Hogue v. Housing Authority of North Little Rock, 201 Ark. 263, 144 S. W. (2d) 49 (1940); State ex rel. Harper v. McDavid, 145 Fla. 605, 200 So. 100 (1941); McNulty v. Owens, 188 S. C. 377, 199 S. E. 425 (1938); Knoxville Housing Authority v. Knoxville, 174 Tenn. 76, 123 S. W. (2d) 1085 (1939).

The case of Cincinnati v. Lewis, 66 Ohio St. 49,63 N. E. 588 (1902), relicd upon by the Ohio Court in its syllabus, interpreted an exemption statute to exclude land 
use which once was public or charitable but has ceased to be such, is entitled to no exemption. ${ }^{84}$ But such concessions are irrelevant. If the Ohio Court had followed prevailing legal and policy norms in its determination of what constitutes a public purpose, all of these technical requirements would have been met; the project would have been found to be both presently and exclusizely for such a purpose.

It is indeed only by the most specious reasoning that the decision of the Ohio Court can be made consistent with that Court's own previously, and recently, announced judicial policy. Only by taking the position, described above, that in the Columbus case it was not determining the constitutionality of a statute but was merely interpreting a statute in such a way as to avoid making it unconstitutional, was the court technically able to maintain an appearance of consistency with its former decision in State ex rel. Ellis $v$. Sherrill. ${ }^{85}$ In issuing mandamus to compel the city manager of Cincinnati to sign a contract with the local housing authority, this decision clearly upheld the constitutionality of the Ohio Housing Authority Statute. The contract, signature of which was decreed, included the provision that the city would furnish municipal services to the property for a serice charge, smaller in amount than full taxes, in lieu of such taxes. ${ }^{80}$ The case was twice briefed and twice argued orally before the Ohio Supreme Court; the first time upon the Cincinnati Housing Authority's demurrer to the seven defenses advanced by the city manager of Cincinnati, in which the Court sustained all but the demurrer to the third defense; ${ }^{87}$ the second

owned by the city of Cincinnati, but located in another taxing district, and rented out for farming purposes (though the money paid by the tenants was used in maintaining the water department of the city). It is difficult to see what bearing this case has on the exemption of a low-rent housing project, which is rented not indiscriminately to all comers at market prices, but only to those of specified need and at rentals based on capacity to pay.

It is interesting to contrast the attitude of the Ohio Court in holding, in the case of American Issue Pub. Co. v. Evatt, 137 Ohio St. 264, 28 N. E. (2d) 613 (1940), that a publishing company incorporated for profit, but controlled by another, non-profit, association, organized solely for the purpose of temperance education, was "an institution used exclusively for charitable purposes" within the Ohio Constitution and statutes.

84. It may be appropriate, when private property is used for purposes other than those for which exemption was granted, to revoke the exemption. But when public property is used for purposes alien to those for which it was acquired, the action which would appear most precisely to fit the crime is an action to compel the public officers to do their duty. Mrandamus, a mandatory injunction, or an action for removal could cure the evil without disruption of public service.

85. 136 Ohio St. 328,25 N. E. (2d) 844 (1940).

86. Record (called the "Pleadings" as printed) in State $\mathfrak{e x}$ rel. Ellis y. Sherrill (No. 27410) pp. 9-10, being paragraphs numbered 13 and 14 of the contract between the city of Cincinnati and the Cincinnati Housing Authority.

87. While no opinion was rendered on this decision, the Court entered the following upon its Journal:

"This cause came on to be heard upon the demurrer of the relator generally to the allegations contained in the answer to relator's petition and in the an- 
time upon the issue of facts raised by this third defense, this decision also being in favor of the Housing Authority. ${ }^{88}$ The fourth, fifth and sixth defenses in the answer of the Cincinnati city manager included attacks on the Housing Authority Act and the proposed contract as in violation of both Section 2, Article I (the equal protection clause) and Section 2, Article XII (the clause limiting the legislative power to grant tax exemption) of the Ohio Constitution, on the grounds, inter alia, that the "private" and "competitive" nature of the enterprise and the receipt of service charges by the city in lieu of taxes violated these sections. ${ }^{89}$ In sustaining the demurrer to these answers, the Court would seem clearly to have both considered and adjudicated these issues in favor of the validity of the Housing Authority Act.

It has been sufficiently demonstrated above that the Ohio Court in the Columbus case could make sense of the rationale that it was merely interpreting a statute in order to avoid making it unconstitutional only by assuming the unexpressed premise that a statute explicitly granting tax exemption to a public housing project is unconstitutional. Since a contrary determination was required for the Sherrill decision, it is difficult to see how the Ohio Court, consistently with stare decisis, can now justify its assumption of such a premise.

But whatever the logical tergiversations of the Ohio Court in its dismissal of the Sherrill case, the practical effect of its present decision, as the Court must have realized, is to nullify the Ohio Housing Authority Act. Because of both a constitutional tax limitation ${ }^{90}$ and a statutory

swer to the amendment and supplement to the petition, and specially to the second defense of the answer on the ground that the respondent has not the legal capacity to maintain the second defense, and was argued by counsel.

"On consideration whereof it is ordered and adjudged that the demurrer be, and the same hereby is, sustained as to the second, fourth, fifth, sixth and seventh defenses, but overruled as to the third defense contained in said answer. ther."

"It is ordered that relator be granted 20 days within which to plead fur-

Docket No. 27410, Court Journal 35, page 441, January Term, Supreme Court of Ohio, decided June 21, 1939.

88. The issue raised by this defense was whether the project planned would constitute low rent housing as defined by the USHA and would be slum clearance within the meaning of the Act. It is the decision on this phase of the case which is reported in State ex rel. Ellis v. Sherrill.

89. Record (Pleadings) in State ex rel. Ellis v. Sherrill (No. 27410) pp. 12-18Answer by City Manager to Petition for Writ of Mandamus.

90. "No property, taxed according to value, shall be so taxed in excess of one per cent of its true value in money for all state and local purposes, but laws may be passed authorizing additional taxes to be levied outside of such limitation, either when approved by at least a majority of the electors of the taxing 
debt limit, ${ }^{91}$ local units in Ohio are for all practical purposes prevented from agreeing to make the USHA-required $20 \%$ local contributions in cash. Hence, if tax exemption cannot be substituted for such contributions, USHA will have to stop its annual contributions. The inevitable result must then be, unless the USHA itself takes over the projects and thus continues their tax exemption as federally owned property, ${ }^{92}$ that project administrators will be forced to charge full "economic" rents, thus excluding the low income families for whom the project was built and making impossible of achievement one of the major objectives of the program. If, furthermore, the certainty of tax exemption is denied to local housing authorities, since it is such certainty which alone insures the continued local contributions upon which the federal contributions are by law conditioned, it will become impossible for municipalities to sell the bonds by which they raise their original $10 \%$ down payment. Both the USHA and private capital wisely require long-term commitments. Because of these practical effects of the decision, the nice distinction that technically the constitutionality of the Ohio Housing Authority Act is unimpeached can hardly impress proponents of slum clearance and public housing in Ohio. It should prove especially unpersuasive both to those administering the various Ohio housing authorities, who, in reliance on the practical meaning of the Sherrill decision, ${ }^{93}$ had proceeded to borrow money and let construction contracts,

district voting on such proposition, or when provided for by the charter of a

Municipal Corporation . . O" Онто Coxsт. Art. XII, $\$ 2$.

Onio Gen. Code Axs. (Page, 1938), $\$ 5625-15$, provides that a two-thirds vote of the members of a political subdivision may, on specified conditions and for specified purposes, authorize the taxing authority of any such subdivision to levy a tax in excess of this limitation.

91. OHIo GEN. Cone AnN. (Page, 1937) §2293-14. It is common lnowledge that many Ohio cities have reached, or exceeded, their debt limitations. See $\$ 2$ of the special Act, 115 LAws OF OHIO 601 (1933), which was passed to enable municipalities to participate in federal projects free from the restrictions of the debt limitations of the Unto Gex. Code Ans. (Page, 1937) §§ 2293-14 to2293-18. This Act was declared an emergency law because "Under the existing law a great many municipalities and other subdivisions of Ohio have issued bonds up to their debt limitations." See also 117 LAws OF OHIO $\$ 26$ (1938). In $\$ 2$ of that Act a legislative finding is recited that "the limitation on the net indebtedness now established by law precludes many subdivisions from participation in federal aid for necessary projects . . ." Investigation would probably reveal that Columbus itself is close to, if not over, the line.

92. This is what the USHA now plans to do. See N. Y. Times, Nov. 15, 1942, §1, p. 48 , col. 4 .

93. That the Ohio authorities and the Federal Government were justified in talieving that the case decided that such projects were tax exempt is confirmed by the reasoning and decision of the Ohio Court of Appeals of Franklin County in its unreported opinion, dated Dec. 28, 1940, in State ex rol. Bartlett v. Thatcher [rev'd on olher grounds, 138 Ohio St. 235,34 N. E. (2d) 440 (1941)]. In its opinion in this case, which 
and to the investors who have purchased the bonds of such authorities. ${ }^{04}$ To many people it must have seemed that if there was ever a case which called for the application of stare decisis, this was such a case.95

The most disturbing aspect of the Ohio-Russell theory is, however, in a final question it raises - assuming that its proponents will follow a consistent policy - about the exercise of governmental powers other than tax exemption. If tax exemption is to be denied to government owned housing projects catering to tenants of the lower-income third of our population, what of direct contributions to such projects? If some ambitious Ohio city should miraculously overcome its debt limitations and succeed in interesting the USHA and private capital without the aid of tax exemption, can it now constitutionally - in the light of the Columbus decision - make direct contributions from tax receipts by way of providing its portion of the necessary annual subsidy for a public housing project? Tax exemption and direct grant, as methods of subsidizing public housing, are obviously functional equivalents."

involved the same property and the same parties as were involved in the Colmmbus case. the court interpreted the Sherrill decision as follows:

"We do not understand the plaintiff in the instant case is seriously contesting the proposition that the property included in Poindexter Village is public property. The gravamen of his contention is that the property is being rented for private use and by reason of that fact is not used exchusively for public usc. In our judgment this question was necessarily raised in the Sherrill casc, wherein was urged the inconstitutionality of the act. . . .

"The stipulation or agreed statement of facts sets out that in the rental of the several units in Poindexter Village the provisions of the act have becn complied with.

"When this is admitted nothing remains. We quite agree that where the public use is diverted to a private use the premises would lose their right of exemption from taxation. Counsel for plaintiff urge very persuasively that the renting of the various units to individuals for private use as a home is not a public use, but, as heretofore stated, this was necessarily the question that was before the Supreme Court in the Sherrill case . . ." (emphasis added).

See also the dissent of Judges Williams and Zimmerman in the Columbus case, at 442:

"Such action [reversal of the decision of the Ohio Board of Tax Appeals refusing tax exemption] would be in harmony with the decision in the case of State $e x$ rel. Ellis, City Solicitor v. Sherrill, City Manager."

94. $\$ 489,000$ of the bonds of the Youngstown Metropolitan Housing Authority were purchased and are now owned by Ohio state sinking funds, consisting of the State Teachers' Retirement Fund, the Public Employees' Retirement Fund, and the Public School Employees' Retirement System.

95. In Meyers v. Rose Institute, 92 Ohio St. 238, 249, 110 N. E. 929, 932 (1915), the Ohio Court suggested that, where a charitable institution had been induced to invest funds in personal property by the apparent fixed policy of the state, as expressed in jttdicial decisions, that charitable institutions could not be taxed on such investments, the case was most appropriate for the application of stare decisis.

96. Proponents of public housing have no cause to be apologetic on policy grounds about tax exemption as a method of subsidizing public housing. Tax exemption places 
It does not seem possible that anyone could seriously argue that tax exemption involves more of an expenditure of public funds than an outright state or municipal grant of funds, and no persuasive policy reason has ever been stated for making a difference in the constitutionality of the two. ${ }^{97}$ The fact is, however, that courts, apparently thinking tax exemption the less painful form of subsidy, have always been more lenient in permitting tax exemption than they have outright grants. ${ }^{03}$

no greater burden on other property owners than does direct grant. Unfortunate as it is that most local revenues are today collected from an antiquated, regressive "real estate" tax, there is no more reason to postpone public housing, than to postpone any other governmental function, until the day when the whole local tax structure has been completely reformed. Mr. Coleman Woodbury, in Citizess' Horsisa Couscu. of X. $\mathrm{X}$. Local Taxation AND Housmig (1939) 66, has well said:

"Nearly all of the drawbacks in tax reduction as a housing subsidy, simply reveal underlying weaknesses in the present system of local government finances. Housing officials themselves are not responsible for these wealmesses. There can be no sense in trying to take out upon this new governmental activity the spite and bad feeling that has accumulated from failure to adapt local taxation to a twentieth century urban civilization."

Nor, it might be added, are the occupants of substandard housing responsible for the inequities of local taxation.

Indeed tax exemption of public housing projects can be regarded as a belated, crude, and indirect recognition that our traditional "real estate" tax is in effect just a sales $\operatorname{tax}$ on homes. Cf. Buttenheim, Unaise Taxation as a Burden on Housing (1938) 48 YALE L. J. 240. Exemption for the purpose of protecting a minimum standard of subsistence, if not of healthful living-such as honestead exemptions and income tax deductions-has, furthermore, long been regarded as consistent with the social and economic norms of our society. See Groves, Finsxcivg Gorerrareit (1939) 480.

The argument that exemption of public housing projects may eventually imperil the "whole local tax structure" is too optimistic. It is most unlikely that public authorities will in the calculable future be able to build on so grand a scale. There will be time enough to take care of the tax problem when such a miracle appears. It would be a great additional public service-clear "unearned increment"-if the public housing program should succeed in forcing quicker public response to the urgent needs both of e:panding tax areas and of shifting to less regressive forms of taxation.

97. MIr. Russell (at 384) suggests that "the nust forthright approach to the problem would be proposals to amend the state constitutions expressly to authorize the exemption" of housing projects. If such exemption is attended by so many anti-sccial consequences, as Mr. Russell alleges, that courts cannot reasonably define "public purpose" to include such exemption, why should a change in the method by which exemption is obtained work a change in the consequences?

98. See Stimson, Exemption of Proporty from Taxalion (1934) 18 Mr:s:. L. REx. 411, 419:

"An examination of court opinions discloses the fact that legislation granting indirect subsidies, in the form of tax exemption, is upheld by the curts. even though a direct subsidy to the same institutions vould be denied under the doctrine of direct public purpose. This is amply illustrated in the case of churches, sectarian schools, and private industrial enterprises . . Courts quite generally have failed to see that tax exemption is a subsidy whose burden rests upon taxpayers."

See also Baker, Tax Exemption Statutes (1928) 7 TEx. L. Rev. 50. 
Hence, since the public purpose concept is now universally held to limit governmental power directly or indirectly to raise or spend tax funds in every jurisdiction, it does not seem possible for the Ohio Court to escape from the conclusion that if a typical USHA-approved project is not a public purpose for tax exemption purposes, a fortiori such projects are not legitimate purposes for which state or local funds can be spent either directly by outright grant or indirectly by the use of government credit. $^{90}$

It is apparent from the above that any finding that a project is not for a public purpose unless it provides only for those of the lowest income, coupled with a definition of "lowest" so narrow that it is synonymous with pauperism, will effectively scuttle the possibilities of participation in the USHA program by any localities in that jurisdiction. It is also apparent that such a decision, if its definition of public purpose carries the concomitant denial of any use of municipal funds or credit, will equally prevent the undertaking of any similar program, not dependent on federal aid, by a state or municipal government unit. Hence there would seem to be no escape from the conclusion that the consequence of the Ohio-Russell doctrine is to prevent all local housing, projects, however financed, except "poor houses" donating their quarters to paltpers. ${ }^{100}$

It is not our purpose, by this meticulous criticism, to exaggerate the importance of a single court decision, or of a single bar journal article, which seeks to overthrow prevailing notions of law and policy. It scarcely seems likely that an aberrant, medieval ideology, stemming from a time when everyman's house was his "castle," will be able to make much headway against the political, social, and economic factors which today condition the housing and planning program. But when a reactionary doctrine gets loose in the law books there is no predicting to what uses unimaginative men or men of ill will may put it. The real danger of the Ohio-Russell theory lies in its implications for the vast proposed post-war program of rebuilding our cities and towns; a program which is being designed not only to provide all citizens with healthful homes in livable communities, but also to cushion postwar unemployment and to salvage what is worth preserving in the many institutions - municipal, banking, insurance, and charitable - whose future is so largely dependent on land values. The urgency of the "land-use" problems which will confront the country in the postwar era admits of no doubt. Even now numerous governmental agencies and private organizations

99. If, furthermore, such projects are not for a "public purpose" to sustain a grant of funds, how rational is it to hold that they are for a "public use" to sustain a grant of eminent domain? Of what value is a power to condemn, if there is no power to pay?

100. We do not overlook the possibility of a wholly federal program. Whether Contgress can be persuaded to be so generous with federal funds is, however, still an open question. 
are working on the necessary plans. Most of these plans call for widescale governmental acquisition of land, to be followed by redevelopment and rebuilding of business centers, transportation terminals, residential areas, and public improvements, by both public and private agencies. ${ }^{101}$ If it is not a "public purpose" for a municipality to contribute one-fifth of the subsidy necessary to house its under-privileged citizens who cannot otherwise secure healthful homes, how much less for a public purpose must be all of the multiple governmental activities which will be required to make effective these post-war plans? Yet such plans must be made effective if the nation is even to begin to achieve the housing and planning goals which now have indubitable public acceptance. Technological resources and manpower will be ample for the implementation of almost any conceivable program. Is it credible that an obsolete, absolutistic, static concept of public purpose, grounded only on a laissez-faire policy of letting the devil take the hindmost, will be allowed to block the way? The necessities of a world soon to come must reconsign the Ohio-Russell theory to the oblivion whence it came.

101. See Cosference on Urbanisu, Harvard University (Greer, ed.), Tue Pronless

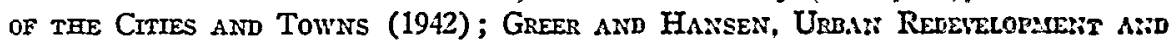
Housing (1941); Federal Housing Aduinistration, A Hundboos o: Cisbas: ReDeVELOPNEATt For Cittes in the UntTed States (1941); and the publieations of NAtrosar Resources Planning Board: Public Land Acquisition, Pabr II: Cimasi Lands (1941), National Resources Deteloparent Refúrt (1942), After tae IiarFuld Exploysent (1942), The House Building Innustry (1942), Betres Ciries (1942). Charles Ascher, author of the last mentioned pamphlet, urges (at 21):

"Let us not quail before the magnitude of the task. A nation that can organize itself for the conduct of war as the United States is now organizing, should have no lack of confidence in its ability to carry out any task that it wilis." 